\title{
Phytochemical Screening, Proximate and Mineral Composition of Sweet Potato Leaves Grown in Tepi Provision, South- west of Ethiopia
}

\begin{tabular}{|c|c|}
\hline \multicolumn{2}{|l|}{ Ahmed Awol } \\
\hline \multicolumn{2}{|c|}{ Department of Chemistry, Mizan-Tepi University, Tepi Campus, Post Box No: 121, Tepi, Ethiopia } \\
\hline Abstract & Article Information \\
\hline $\begin{array}{l}\text { Leaves of sweet potato (Ipomoea batatas) grown in Tepi area was studied for their class of } \\
\text { ohytochemicals, mineral and proximate composition using standard analytical methods. The } \\
\text { ohytochemical screening revealed the presence of alkaloids, flavonoid, terpenoids, saponins, } \\
\text { quinones, phenol, tannins, amino acid and proteins in the leaves. The proximate composition }\end{array}$ & $\begin{array}{l}\text { Article History: } \\
\text { Received : } 20-06-2014 \\
\text { Revised : } 19-09-2014 \\
\text { Accepted : } 25-09-2014\end{array}$ \\
\hline $\begin{array}{l}\text { crude fiber }(12.62 \pm 0.39 \% \text {, DW }) \text {, crude protein }(6.37 \pm 0.13 \% \text {, DW }) \text { and carbohydrate } \\
(69.62 \pm 0.69 \%) \text {. The minerals composition revealed potassium }(3608.854 \mathrm{mg} / 100 \mathrm{~g}) \text {, sodium } \\
(32.079 \pm 0.12 \mathrm{mg} / 100 \mathrm{~g}) \text {, calcium ( } 320.125 \pm 0.36 \mathrm{mg} / 100 \mathrm{~g}) \text {, magnesium }(118.75 \pm 0.02 \mathrm{mg} \\
(100 \mathrm{~g}) \text {, copper }(1.828 \pm 0.11 \mathrm{mg} / 100 \mathrm{~g}) \text {, zinc }(5.647 \pm 0.14 \mathrm{mg} / 100 \mathrm{~g}) \text {, iron }(73.881 \pm 0.03 \mathrm{mg} / 100 \mathrm{~g})\end{array}$ & $\begin{array}{l}\text { Keywords: } \\
\text { Mineral composition } \\
\text { Proximate composition } \\
\text { Phytochemicals } \\
\text { Sweet potato } \\
\text { Ipomoea batatas }\end{array}$ \\
\hline $\begin{array}{l}\text { and manganese }(9.590 \pm 0.06 \mathrm{mg} / 100 \mathrm{~g}) \text {. These results revealed that the leaves of sweet } \\
\text { ootato (Ipomoea batatas) contained essential nutrients which compare favorably well with } \\
\text { those of wild edible leaves in literatures. } \\
\text { Copyright@2014 STAR Journal. All Rights Reserved. }\end{array}$ & $\begin{array}{l}{ }^{*} \text { Corresponding Author: } \\
\text { Ahmed Awol } \\
\text { E-mail: } \\
\text { ahmedawol44@yahoo.com }\end{array}$ \\
\hline
\end{tabular}

\section{INTRODUCTION}

Vegetables are the fresh and edible portions of herbaceous plants, which can be eaten raw, or cooked (Oyenuga and Fetuga, 1975, Fayemi, 1999, Dhellot et al., 2006, Hassan et al., 2007). Vegetables are valuable in maintaining alkaline reserve of the body. They are valued mainly for their high carbohydrate, vitamin and mineral contents. Vegetables may be edible roots, stems, leaves, fruits or seed. Each group contributes to diet in its own way (Robinson, 1990). However, there are some used and inexpensive leafy vegetables whose nutritive and anti-nutritive potentials are yet to be adequately studied and utilized. Among these leafy vegetables are the leaves of sweet potatoes. Sweet potato (Ipomoea batatas) is a herbaceous creeping plant with smooth, lightly moderate green leaves sometimes with a considerable amount of purple pigmentation especially along its veins (Longe, 1986). Its starchy tuberous root is the major economic part of the crop.

Occasionally, the leaves are used as vegetable in yam and cocoyam porridges in some parts of Nigeria particularly among the Efik-Ibibio people of South-Eastern Nigeria (Eka and Edijala, 1972). Islam et al. (2002) further reported that, Ipomoea batatas leaves as an excellent source of antioxidative polyphenolics compared to other commercial vegetables. Though consumed in Asia and some sub-Saharan countries (Duke, 1983), they have generally been regarded as an underexploited green vegetable. Abbiw (1990) listed Ipomoea batatas as one of the vegetables consumed by all ethnic groups in Ghana. However, it must be noted that only the storage roots are consumed in large quantities. Yoshimoto et al. (2002) considered sweet potato leaf tougher in terms of texture than other leafy vegetables.

Besides being used for human consumption, the leaves serve as fodder and browse for cattle, sheep, goats, pigs and other domestic animals. According to Oyenuga (1968), the young leaves of sweet potatoes serve as a good vegetable source for man. Its wide use as vegetable is however hampered by the fact that it is considered a poor man's vegetable, coupled with the fact that it had always been used traditionally as feeds for domestic animals. Much attention in most literatures has only been paid to the tubers and not the leaves. Since there is very little or no information on the true chemical composition of Ipomoea batatas leaves grown in Tepi, Ethiopia, the processing of the leaves for nutritional or therapeutic purposes may be misleading. The population unaware of the high nutritional and nutraceutical values of these vegetables, grow sweet potatoes, wait for the storage roots to mature, harvest and discard the leaves or serve them as animal feed. This work is therefore aimed at finding out the proximate composition, mineral compositions and phytochemical screening of sweet potato leaves in a bid to determining its suitability as an edible vegetable or not.

\section{MATERIALS AND METHODS}

Sample Collection

The leaves of Ipomoea batatas was collected from Tepi area farm land, Ethiopia. The leaves were destalked, 


\section{Ahmed Awol}

washed with deionized water to remove the impurities and sunlight dried. After drying, the leaves were ground into a fine powder using a mortar and pestle, and then sieved and stored in a well labeled air-tight container for analysis.

\section{Qualitative Phytochemical Screening}

Phytochemical tests on the leaves of Ipomoea batatas were carried out using standard analytical procedures as described by Sofowora (1993), Harborn (1973) and Evans (2002).

\section{Proximate Analysis}

The Ipomoea batatas leaves was analyzed for proximate constituents; moisture, total ash, crude fat and crude fiber using the methods of Association of Official Analytical Chemists (AOAC, 1990) in JIJE Analytical Testing Service Laboratory in Addis Ababa, Ethiopia. While nitrogen was determined by micro-Kjeldahl method as described by Pearson (1976) and the percentage nitrogen was converted to crude protein by multiplying the value with 6.25 . To determine the total carbohydrate, the method of James (1995) based on the difference was employed.

\section{Mineral Analysis}

Test for the presence of minerals was carried out after acid digestion. The supernatant was decanted and the liquid was analyzed for the levels of $\mathrm{Ca}, \mathrm{Na}, \mathrm{K}, \mathrm{Cu}, \mathrm{Fe}$, $\mathrm{Zn}, \mathrm{Mg}$ and $\mathrm{Mn}$. Sodium and Potassium levels were analyzed using flame photometer. Calcium, Magnesium, Iron, Zinc, Copper and Manganese were determined using atomic absorption spectrophotometer.

\section{RESULTS AND DISCUSSION}

The qualitative phytochemical screening of Ipomoea batatas leaves (Table 1) reveals the presence of Tannins, Saponins, Flavonoids, Terpenoids, Quinones, Phenol, Amino acid and Protein. The reported health benefits of Ipomoea batatas leaves may be attributed to these phytoconstituents that might be of medicinal value (Figure 1).

Table 1: Results of the qualitative phytochemical screening of Ipomoea batatas leaves

\begin{tabular}{|c|c|c|c|}
\hline \multirow{2}{*}{$\begin{array}{l}\text { Phytochemical } \\
\text { constituents }\end{array}$} & \multicolumn{3}{|c|}{ Solvents Used for Extraction } \\
\hline & $\begin{array}{l}\text { Water } \\
\left(\mathrm{H}_{2} \mathrm{O}\right)\end{array}$ & $\begin{array}{c}\text { Methanol } \\
\left(\mathrm{CH}_{3} \mathrm{OH}\right)\end{array}$ & Cyclohexane \\
\hline Alkaloids & + & + & - \\
\hline Flavonoids & + & + & - \\
\hline Terpenoid & + & + & - \\
\hline Saponins & + & + & - \\
\hline Quinones & + & + & - \\
\hline Phenol & + & + & - \\
\hline Tannin & + & + & - \\
\hline $\begin{array}{l}\text { Amino acid and } \\
\text { proteins }\end{array}$ & + & + & - \\
\hline
\end{tabular}

+ Present, - Absent, assay were carried out in triplicates

The proximate analysis of Ipomoea batatas leaves revealed that it contain an appreciable amount of carbohydrate $(69.62 \%)$. This value is higher than the values reported for pterocarpus soyansii $46.66 \%$ and pterocarpus santalinoides $51.37 \%$ Ndukwe, (2013). This means that every $100 \mathrm{~g}$ of Ipomoea batatas leaves should contain $69.62 \mathrm{~g}$ of carbohydrate. Carbohydrate also serves as stored forms of energy as glycogen in liver and
Sci. Technol. Arts Res. J., July-Sep 2014, 3(3): 112-115

muscles. It also provides major source of energy and responsible for breaking-down of fatty acids and preventing ketosis (Hassan and Umar, 2006).

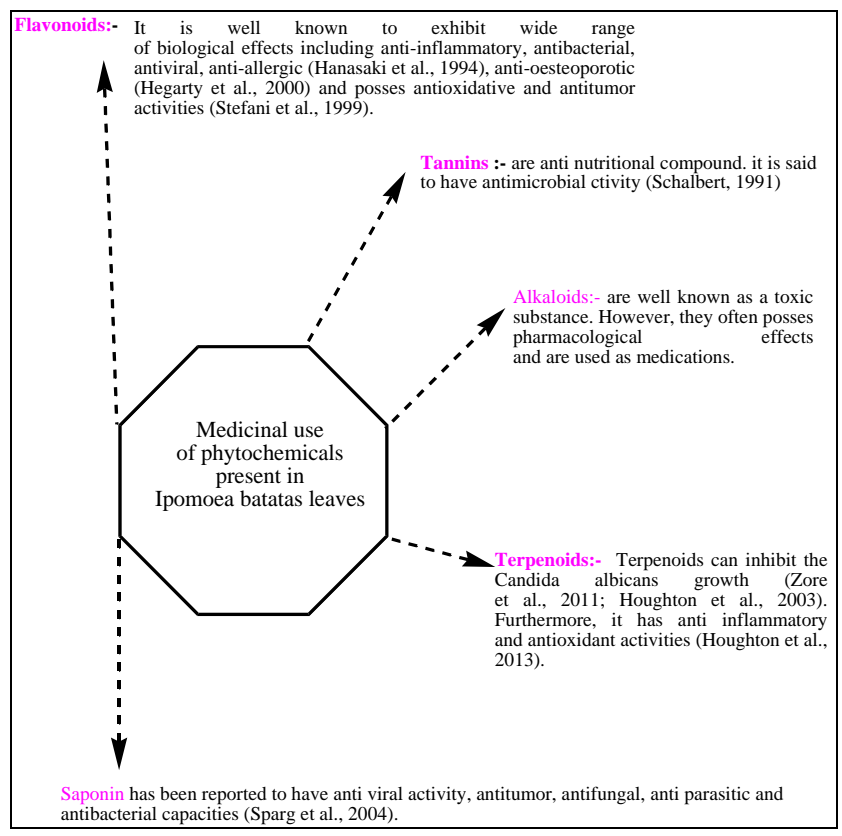

Figure 1: Medicinal uses of Ipomoea batatas leaves

Protein is used for building and repairing of body tissues, regulation of body processes and formation of enzymes and hormones. Proteins also aid in the formation of antibodies that enable the body to fight infection. Proteins serve as a major energy supplier (Brosnan, 2003). Proteins are responsible for the formation of bones, teeth, hair and the outer layer of skin and they help maintain the structure of blood vessels and other tissues. The protein content of Ipomoea batatas leaves (6.37\%). The concentration is relatively lower compared to the $35.9 \%$ reported by Ekuagbere (2007) for calabash seed, $43.1 \%$ for luffa cylindrical kernel (Olaofe et al., 2008) and the $23.7-30.8 \%$ for gourd seed (Olaofe et al., 1994). The result revealed that the leaves Ipomoea batatas leaves are a source of protein.

The cured fat content of Ipomoea batatas leaves is $3.80 \%$, which was low in amount when compared to those of groundnut (43\%) (Apata and Ologhobo, 1994), alinum triangulare $(5.09 \%)$, Amarantus hybridus (4.80\%) (Akindahunsi and Salawu 2005) and calabash seed (43\%) (Ekuagbere, 2007), the findings of this study showed that, the Ipomoea batatas leaves is a poor source of plant fat (lipid), which is in agreement with general observation that leafy vegetables are low lipid containing food, thus, advantages health use in avoiding obesity (Lintas, 1992). The crude fiber content of Ipomoea batatas leaves is $12.62 \%$. This value is higher than that of Gnetum africanum (4.60), M. ureans (4.00) and Parinari polyandra (Ekpo, 2007). The substantial amount of fiber in all the vegetables shows that they can help in keeping the digestive system healthy and functioning properly. Fiber aids and speeds up the excretion of waste and toxins from the body, preventing them from sitting in the intestine or bowel for too long, which could cause a build-up and lead to several diseases, reduce serum cholesterol level, hypertension, diabetes, breast cancer and constipation (Hunt et al., 1980, Ishida et al., 2000). Thus, the Ipomoea batatas leaves could be valuable sources of dietary fiber. 


\section{Ahmed Awol}

The ash content $13.74 \pm 0.013 \%$ indicates that the leaves are rich in mineral elements. The value obtained is higher compared to $1.8 \%$ reported in sweet potato leaves (Asibey-Berko and Tayie, 1999), 10.83\% in water spinach leaves and $5 \%$ in Tribulus terrestris leaves, but lower than $19.61 \%$ in Amaranthus hybridus leaves (Nwaogu et al., 2000) and $18.00 \%$ Balsam apple leaves (Hassan and Umar, 2006). The ash content is a reflection of the amount of mineral elements present in the samples; therefore, the Ipomoea batatas leaves contained a good amount of minerals.

\section{Mineral Content}

The mineral composition of Ipomoea batatas leaves was evaluated in the present study. Potassium is necessary for the function of all living cells and is thus present in all plant and animal tissues. Epidemiological studies and studies in animals subject to hypertension indicate that, diets high in potassium can reduce the risk of hypertension and possibly stroke. The present study revealed that the potassium content of Ipomoea batatas leaves $(3608.854 \mathrm{mg} / 100 \mathrm{~g})$. Thus, the Ipomoea batatas leaves could serve as a good source of potassium for the hypertensive patient especially pregnant women that are prone to high blood pressure toward the period of delivery. Sodium is an essential element that is necessary for humans to maintain the balance of the physical fluids system. It is also required for nerve and muscle functioning. Sodium content of Ipomoea batatas leaves was $(32.079 \mathrm{mg} / 100 \mathrm{~g})$.which shows a close agreement with the values reported for bitter leaf $26.05 \mathrm{mg} / 100 \mathrm{~g}$ and soybean $35.85 \mathrm{mg} / 100 \mathrm{~g}$ (Chuku and Ugorji, 2012). The obtained value is lower than $805.60 \pm 0.01 \mathrm{mg} / 100 \mathrm{~g}$ and $196.80 \pm 0.02 \mathrm{mg} / 100 \mathrm{~g}$ reported for the leaves and stems of Balanites aegyptiaca (Idris et al., 2010).

Magnesium is an important mineral element in connection with circulatory diseases such as ischemic heart disease and calcium metabolism in bone (Ishida et al., 2000, Hassan and Umar, 2006). The magnesium content of the leaves is $118.750 \pm 0.02 \mathrm{mg} / 100 \mathrm{~g}$ which is high compared with $2.56 \mathrm{mg} / 100 \mathrm{~g}$ in Diospyros mespiliformis (Hassan et al., 2004), 23.18 \pm 0.4 of Amaranthus hybridus leaves (Nwaogu et al., 2000) and lower than $400.00 \pm 00.00 \mathrm{mg} / 100 \mathrm{~g}$ in Cassia siamea leaves (Ngaski, 2006).

Calcium is an important component of a healthy diet and a mineral necessary for life. It plays an important role in building strong and dense as well as in the keeping of healthy bones and teeth both early and later in life. Calcium content of Ipomoea batatas leaves was (320.125 $\mathrm{mg} / 100 \mathrm{~g}$ ). It is higher than the values obtained for spinach $14.55 \mathrm{mg} / 100 \mathrm{~g}$, bitter leaf $150 \mathrm{mg} / 100 \mathrm{~g}$, okra $50.8 \mathrm{mg} / 100 \mathrm{~g}$ but less than soybean $480 \mathrm{mg} / 100 \mathrm{~g}$ (Chuku and Ugorji, 2012). Thus, the Ipomoea batatas leaves could serve as a good source of calcium for building strong and dense as well as in the keeping of healthy bones and teeth.

Copper has a number of important functions in the human body. It helps to produce red and white blood cells and triggers the release of iron to form hemoglobin (the substance that carries oxygen around the body). Copper content of Ipomoea batatas leaves was 1.828 $\mathrm{mg} / 100 \mathrm{~g}$. The result of the present study shows that, the Ipomoea batatas leave is a good sources of copper relative to its recommended dietary allowance (RDA) of 1.5-3 mg/day for adult male and female, pregnant and
Sci. Technol. Arts Res. J., July-Sep 2014, 3(3): 112-115

lactating mothers and 1-3 mg/day for children (7-10 years) (NRC, 1989).

Iron is required for haemoglobin formation and its deficiency leads to anaemia (Turan et al., 2003). The iron content of Ipomoea batatas leaf was found to be $73.881 \pm 0.03 \mathrm{mg} / 100 \mathrm{~g}$ which is higher than $2.80 \pm 0.7$ $\mathrm{mg} / 100 \mathrm{~g}$ in $T$. terrestris in some cultivated vegetables such as spinach $(1.6 \mathrm{mg} / 100 \mathrm{~g})$ lettuce $(0.7 \mathrm{mg} / 100 \mathrm{~g})$ and cabbage $(0.3 \mathrm{mg} / 100 \mathrm{~g})$ (Turan et al., 2003) but lower than $84.4 \mathrm{mg} / 100 \mathrm{~g}$ in Helminthostachys sp. The leaves of Ipomoea batatas are rich sources of iron, and could be of good use to pregnant women, lactating mothers. Generally for women since they loss some quantity of blood during monthly menstruation, it could help in the nourishing of their bodies.

Manganese plays an important role in number of physiologic processes as a constituent of some enzymes and an activator of other enzymes. Concentration of manganese in Ipomoea batatas leave was found to be $9.59 \pm 0.06 \mathrm{mg} / 100 \mathrm{~g}$. When compared to the RDA for manganese which are $2-5 \mathrm{mg} /$ day for adult male and female, pregnant and lactating mothers and 2-3mg/day for children (7-10 years) (NRC, 1989), the Ipomoea batatas leave of this plant cannot serve as a manganese supplement because of excessive manganese it contain which exceeded the RDA.

Different enzyme systems in the body require mineral zinc as cofactor. These enzyme systems are responsible for every major physiological function that necessitates catalytic activity from enzyme at the molecular level. Zinc concentration was found in the Ipomoea batatas leave was found to be $5.647 \pm 0.14 \mathrm{mg} / 100 \mathrm{~g}$, which is high compared to garcinia kola $3.67 \pm 0.01 \mathrm{mg} / 100 \mathrm{~g}$ (Adesuyi et al., 2012). Zinc content of the leaves of this plant cannot serve as a zinc supplement when compared to the zinc RDA of $10 \mathrm{mg} /$ day for children (7-10 years), $12 \mathrm{mg} /$ day for adult female, $15 \mathrm{mg} /$ day for adult and $19 \mathrm{mg} /$ day for pregnant and lactating mothers (NRC, 1989), and to be able to meet the daily requirements, it should be taken in large quantities.

\section{CONCLUSIONS}

In conclusion, Ipomoea batatas leaves are an important plant not only as food but also as medicine, due to the presence of various phytochemical constituents. The result of the mineral composition also reveals its high content of minerals such as $\mathrm{Mn}, \mathrm{Ca}, \mathrm{Na}, \mathrm{Zn}, \mathrm{K}, \mathrm{Mg}$ and $\mathrm{Fe}$ indicating its relevance and indispensable roles in solving many mineral related problems in the consumers. Some of these minerals are useful in patient suffering from bone thinning, adult rickets, bone fraction, bone leaching or bone weakening. The high carbohydrate content provides major source of energy and responsible for breaking down of fatty acids and preventing ketosis.

\section{REFERENCES}

Abbiw, D.K. (1990). Traditional vegetables in Ghana. Department of Botany, University of Ghana, Legon, Ghana.

Akindahunsi, A.A. and Salawu, S.O. (2005). Phytochemical and nutrient composition of selected tropical green leafy vegetables. African Journal of Biotechnology 4: 479-501.

Apata, D.F. and Ologhoba, A.D. (1994). Biochemical evaluation of some Nigerian legume seeds. Food Chemistry 49: 333-338. 
Ahmed Awol

Asibey-Berko, E. and Tayie, F.A.K. (1999). Proximate analysis of some underutilized Ghannian vegetable. Ghana Journal of Sciences 39: 91-92.

Brosnan, J. (2003). Interorgan amino acid transport and its regulation. Journal of Nutrition 133: 2068-2072.

Dhellot, J.R., Matouba, E., Maloumbi, M.G., Nzikou, J.M., Safou-Ngoma, D.G., Linder, M., Desobry, S. and Parmentier, M. (2006). Extraction, chemical composition and nutritional characterization of vegetable oils: Case of Amaranthus hybridus (Var 1 and 2) of Congo Brazzaville. African Journal of Biotechnology 5(11): 1095-1101.

Duke, J.A. (1983). Ipomoea batatas. Handbook of Energy Crops. Unpublished. [http://www.hort.purdue.edu/new crop/ default.html].

Chuku, E.C. and Ugorji, J.H. (2012). Determination of levels of some nutrients and ant nutrients in five selected vegetables in Niger delta. Scienta Africana 11(1):130-142.

Eka, O.U. and Edijala, J.K. (1972). Chemical Composition of some traditionally prepared Nigerian Food. Journal of Biological and Applied Chemistry 6: 177.

Ekop, A.S. (2007). Determination of chemical composition of Gnetum Africana (AFANG) seeds. Pakistan Journal of Nutrition 6(1): 40-43.

Ekuagbere, A.O. (2007). Chemical, mineral and amino acid composition and functional properties of calabash seed, pp. 24-36.

Evans, W.C. (2002). Trease and Pharmacognosy. $15^{\text {th }}$ Edn., Bailliere Tindall, London.

Fayemi, P.O. (1999). Nigerian Vegetables, Heinemann Educational Books Nigeria, $1^{\text {st }}$ Edition pp. 1-8.

Hanasaki, Y., Ogawa S. and Fukui S. (1994). The correlation between active oxygens scavenging and antioxidative effects of flavonoids. Free Radical Biology and Medicine 16: $845-850$.

Harborne, J.B., (1973). Text book of phytochemical Methods. $1^{\text {st }}$ Edn., Champraan and Hall Ltd., London, pp: 110-113.

Hassan, L.G., Umar, K.J. and Tijjani, A.A. (2007). Preliminary Investigation on the feed quality of Monechma cilition Seeds. ChemClass Journal 4: 83.

Hassan, L.G., Umar, K.J. and Tijjani, A.A. (2006). Nutritonal value of balsam apple (Momordica balsamina L.) leaves. Pakistan Journal of Nutrition 5:522-529.

Hegarty, V.M., May, H.M. and Khaw, K.T. (2000). Tea drinking and bone mineral density in older women. American Journal of Clinical Nutrition 71: 1003-1007.

Houghton, P.J., Mensah, A.Y., lessa, N. and Hong, L.Y. (2003). Terpenoids in Buddleja: relevance to chemosystematics, chemical ecology and biological activity. Phytochemistry 64: 385-393.

Hunt, S., Groff, I.L. and Holbrook, J. (1980). Nutrition, Principles and Chemical Practice. John Wiley and Sons, New York, 49-52; 459-462.

Ishida, H., Suzuno, H., Sugiyama, N., Innami, S., Todokoro, T. and Maekawa, A. (2000). Nutritional evaluation of chemical component of leaves stalks and stems of sweet potatoes (Ipomea batatas Poir). Food Chemistry 68: 359367.

Islam, S.M., Yoshimoto, M., Yahara, S., Okuno, S., Ishiguro, K. and Yamakawa, O. (2002). Identification and Characterization of Foliar Polyphenolic Composition in Sweetpotato (Ipomoea batatas L.) Genotypes. Journal of Agricultural Food Chemistry 50: 3718-3722.

James, C.S. (1995). Anlytical chemistry of foods. $1^{\text {st }}$ Edn., Chapman and Hall, New York.
Sci. Technol. Arts Res. J., July-Sep 2014, 3(3): 112-115

Lintas, C. (1992). Nutritional aspects of fruits and vegetables consumption. Options Mediterraneennes 19: 79-87.

Longe, O.G. (1986). Energy Content of some tropical starch crop in Nigeria. Journal of Agriculture 21: 134-136.

National Research Council. (1989). Recommended Dietary Allowances. National Academy Press, Washington DC.

Ngaski, M.M. (2006). Phytochemical screening and proximate analysis of Cassia siamea leaves. M.Sc. Dissertation (Unpublished). Submitted to postgraduate school, Usmanu Danfodiyo University, Sokoto.

Ndukwe, O.K. (2013). Comparative evaluation of the phytochemical and proximate constituents of $\mathrm{OHA}$ (pterocarpus sayonsii and pterocarpus santalinoids) leaves. International Journal of Academic Research in Progressive Education and Development 2(3):2226-6348.

Nwaogu, L.A., Ujowndu, C.O. and Mgbemena, A.I. (2000). Studies on the nutritional and phytochemical composition of Amarantus hybridus leaves. Bio-Resources 4: 28-31.

Olaofe, O., Okiribiti, B.Y. and Aremu, M.O. (2008). Chemical Evaluation of the Nutritive Value of Smooth Luffa (Luffa cylindrical) Seeds and Kernel, Electronic Journal of Environmental, Agricultural and Food Chemistry 3444-52.

Olaofe, O., Umar, Y.O. and Adediran, G.O. (1994). The effect of nematicides on the nutritive value and functional prop. of cowpea seeds. (Vigna unguiculata L. Walp), Food Chemistry 46: 337-341.

Oyenuga, V.A. and Fetuga, B.L. (1975). First National Seminar on Fruits and Vegetables. In: proc. And Recom. \& papers by NIHORT, Ibadan.

Oyenuga, V.A., (1968). Nigerian Food and Feeding stuffs, their chemistry and Nutritive value; 3rd ed. University press Ibadan, Nigeria

Pearson, D. (1976). The chemical analysis of foods. $7^{\text {th }}$ Edn., Churchill Livingstone, London, pp:7-11.

Robinson, D.S. (1990). Food biochemistry and nutritional value. Longman scientific and technical publisher, New York. USA.

Schalbert, A. (1991). Antimicrobial properties of tannins. Phytochemistry 30(12): 3875-3883

Sofowora, A. (1983). Medicinal plants and Traditional medicine In Africa $2^{\text {nd }}$ Edn., Spectrum Books Ltd., Ibadan, Nigeria. Pp: 289.

Sparg, S.G., Light, M.E. and Van Staden, J. (2004). Biological activities and plant distribution of saponins. Journal of Ethnopharmacology 94: 219-243.

Stefani, E.D., Boffetta, P and Deneo-Pellegrini, H. (1999). Dietary antioxidants and lung cancer risk: A case-control study in Uruguay. Nutrition and Cancer 34:100-110.

Turan, M., Kordali, S., Zengin, H., Dursun, A. and Sezene, Y. (2003). Macro and Micro mineral content of some wild edible leaves consumed in Eastern Anatolia. Acta Agriculturae Scandinavica, Section B -Soil and Plant Science 53: 129-137.

Yoshimoto, M., Yahara, S., Okuno, S., Islam, S., Ishiguro, K., Yamakawa, O. (2002). Antimutagenicity of Mono- Di-, and Tricaffeoylquinic Acid Derivatives Isolated from Sweetpotato (Ipomoea batatas L.) Leaf. Bioscience, Biotechnology, and Biochemistry 66 (11): 2336-2341.

Zore, G.B., Thakre, A.D., Jadhav, S. and Karupayyil, S.M. (2011). Terpenoids inhibit Candida albicans growth by affecting cell integrity and arrest of cell cycle. Phytomedicine 18: 1181-1120. 